HSTC Bulletin

Journal of the History of Canadian Science, Technology and Medecine

hstc

Revue d'histoire des sciences, des techniques et de la médecine au Canada

bulletin

\title{
Canadian Inventory of Historic Technology
}

\section{W. George Richardson}

Volume 4, numéro 2 (14), february 1980

URI : https://id.erudit.org/iderudit/1081531ar

DOI : https://doi.org/10.7202/1081531ar

Aller au sommaire du numéro

Éditeur(s)

HSTC Publications

ISSN

0228-0086 (imprimé)

1918-7742 (numérique)

Découvrir la revue

Citer ce document

Richardson, W. G. (1980). Canadian Inventory of Historic Technology. HSTC

Bulletin, 4(2), 4-6. https://doi.org/10.7202/1081531ar d'utilisation que vous pouvez consulter en ligne.

https://apropos.erudit.org/fr/usagers/politique-dutilisation/ 
Archivists may find the seminars on Preservation and Restoration of Photographic Images, offered by the College of Graphic Arts and Photography of the Rochester Institute of Technology, of interest. These will take place on 3-5 March and 25-27 August. Further information may be obtained from Val Johnson, RIT-GARC, One Lomb Memorial Dr., Rochester, NY 14623.

\section{CANADIAN INVENTORY OF HISTORIC TECHNOLOGY}

Many of us who are interested in the history of technology in Canada have bemoaned the fact that we have no programme equivalent to the Historic American Engineering Record (established 1969). It was hoped that the programme called the Canadian Engineering Heritage Record which was established in 1972 would eventually compile an inventory of historic technology through the efforts of enthusiastic volunteers. Unfortunately the project failed to attract much interest and gradually expired.

In 1978, I began to conceive of a plan for a pilot project involving paid teams of students conducting a survey under closely supervised conditions. My Dean gave me his immediate support for the concept and permission to use Queen's facilities and seed money of $\$ 1,000$. I visited the HAER staff in Washington and came away with forms, diagrams, instruction booklets and advice. Parks Canada, of the Federal Department of Indian and Northern Affairs, and the Heritage Administration Branch of the Ontario Ministry of Culture and Recreation were contacted and they were interested but were unable to supply any funds at this time.

Finally, an application was made to the Federal Department. of Manpower and Immigration for a Young Canada Works Programme Grant. The application requested funds for $\$ 18,462$ for seven student researchers and expenses for sixteen weeks. A sum of $\$ 5,400$ was finally approved to hire three students for twelve weeks and to cover some minimal transportation equipment expenses. No funds were applied for or granted as an extra salary to me as project supervisor. The starting date was May 14, 1979.

The local office of Manpower selected several university students with appropriate background, from whom I chose two students who were just completing their final year of honours history and one graduate of honours Geography. Very few engineering students would work for such low wages and those who would were not suitable. The students were mainly chosen for their enthusiasm and maturity.

The three students were organized into one team and were given some introductory training and assistance in preparing their research plan. The criteria adopted for the survey was as follows:

(a) a structure must be at least 50 years old 
(b) it must contain a whole building and contents or a complete technical process which could provide material for a detailed examination in Phase 2.

(c) it must be a permanent site - in other words no movable items such as farm machinery would be surveyed; this therefore excluded sites with no buildings or just a foundation which was really the task of an archeologist. It also excluded mines unless there was substantial surface buildings.

(d) no restriction was made on the number of similar items found. For example, all fifty year old bridges were recorded whether or not they were unique. It was felt that the statistics on these items would be valuable.

The plan was to survey Frontenac County first, beginning with the City of Kingston, followed by the rural areas; if there was time adjacent counties would also be surveyed. As it turned out we completed our survey of Kingston and Frontenac county in six and half weeks. I decided to vary the approach for Lennox and Addington county to give us the additional experience; we narrowed down our search to bridges and mills which gave us a simpler yet important theme and also made our contacts with the residents much easier. This survey took three weeks, and for the remaining two weeks we concentrated on looking for bridges only in Leeds County.

Results of the project were very encouraging; I am very familiar with the areas surveyed, I can say with some assurance that the survey was reasonably complete, that is, the team probably located at least $75 \%$ of the surviving structures. Most of the team's time was spent in the field rather than producing detailed histories of each structure. However, this research can usually be carried out at a later date. The important result is that detailed records were kept of the following:

(a) training procedures

(b) allocation of time for training, planning, communication with residents and officials, fieldwork, travelling time and historical research

(c) communication procedures

(d) travelling arrangements

(e) background research

(f) recording procedures

(g) photographic records

(h) weather conditions

(i) costs for salaries, transportation, general supplies, photographic supplies, communication (mail, telephone). 
From these records a detailed report was compiled which has enough information to plan a larger survey at the Provincial or preferably at the Federal level. The report analyses the whole project in detail and makes a strong plea for the adoption of such a program at the Federal level. Also included is a detailed estimate of an enlarged programme to complete the survey for all of Eastern Ontario.

It is my firm conviction that if the financial support can be found the programme can be implemented and we might yet develop a clear picture of how much technology has survived. This is absolutely essential if we are to gain some insight into the role of technology in Canadian Society.

- W. George Richardson Queen's University

\section{COMMENT}

I wish there were a whole lot more George Richardsons in Canada! At the present time, the project he has described in his report will help to fill the gap between the demise of the Canadian Engineering Heritage Record and the work expected from the New Heritage Committee of the Engineering Institute of Canada, which is in the process of being set up.

As the Richardson report shows, the business of inventorytaking in industrial archaeology can be pursued quite efficiently using the summer help of University students and a technical consultant. The students themselves need not know a great deal about engineering. But the projcet director, doubling as the consultant, needs to know his way through the thickets of government financial support programs for summer jobs, and especially during times of spending restraints in the public sector.

The Americans have, once again, shown us the way as far as the actual inventorying is concerned. We need not feel badly about this. There will be things we can teach them when we have the necessary experience. And, in any case, one of the lessons of industrial history is that you should be wary about the reinvention of the wheel, unless you can design a very much better one.

As a mechanical engineer, I would like to see future projects of the kind described by Richardson take more time to seek out mechanical artifacts, and receive financial support for preservation - by the appropriate specialists - and the eventual display of them in the museums that are springing up in so many places these days. 